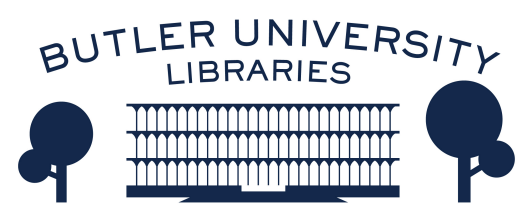

Journal of Hindu-Christian Studies

Volume 19

Article 18

January 2006

\title{
Book Reviews: "Christianity with an Asian Face," "In Our Own Tongues," and "Being Religious Interreligiously"
}

Reid B. Locklin

Follow this and additional works at: https://digitalcommons.butler.edu/jhcs

Part of the Religion Commons

\section{Recommended Citation}

Locklin, Reid B. (2006) "Book Reviews: "Christianity with an Asian Face," "In Our Own Tongues," and "Being Religious Interreligiously"," Journal of Hindu-Christian Studies: Vol. 19, Article 18.

Available at: https://doi.org/10.7825/2164-6279.1373

The Journal of Hindu-Christian Studies is a publication of the Society for Hindu-Christian Studies. The digital version is made available by Digital Commons @ Butler University. For questions about the Journal or the Society, please contact cbauman@butler.edu. For more information about Digital Commons @ Butler University, please contact digitalscholarship@butler.edu. 
56 Book Reviews

critical of the church, saddened that it had given India 'so much evidence of worldliness. . . It is easy to assume that he himself had left the church behind, that he was seeking, and had almost found, a God beyond the church. . . It was as if he was caught between another pair of oppositesone familiar to many Christians todayexasperation with the shortcomings of the church and the recognition that it has a role to play, that structures can have value."(201202)

However, the root of Abhishiktananda's difficulties with the Church laid in his powerful experiences in India, and is probably quite different from current Western disenchantment with institutional religion. Many Advaitic texts report that ultimate reality, Brahman, is utterly different from the world of empirical experience. Hence, the universe often seems unreal and insignificant to people after they have become aware of Brahman. In sharp contrast to this, a classic Christian doctrine is that God became human. Hence, the route to God lies in rituals and institutions. Advaita fundamentally contradicts this aspect of the Christian message, teaching that temporal realities cannot lead one to the Godhead. As Abhishiktananda explained, "The abyss between Christianity and Hinduism seems to me more and more to be this: Christianity, born in a climate of JudeoGreek thought, is basically realist. The West has taken man seriously, as well as the Earth which upholds him. Not so the East. Man is the measure of all, said the Greeks: man and things are part of being, substance. Hence the value of dogmas, of the Incarnation, the agonizing importance of the present life. But for us Hindus, such a view of reality has no meaning."

$\mathrm{Du}$ Boulay is primarily a biographer, whose former topics include the life and thought of Desmond Tutu and Teresa of Avila. Her current book is a solid contribution to the literature on Abhishiktananda. Raimundo Panikkar and Bettina Bäumer, who both knew Abhishiktananda personally, praise du Boulay's book. Yet, if she had provided more background information on Advaita and Christianity, Abhishiktananda might appear less as a rebel against institutional religion and more as someone who mediated between two ancient traditions, exploring with creative integrity the tensions which occur between them.

Edward T. Ulrich

University of St. Thomas

cxxxv Abhishiktananda, Ascent to the Depth of the Heart: The Spiritual Diary (1948-1973) of Swami Abhishiktananda (Dom H.Le Saux), trans. David Fleming and James Stuart (Delhi: ISPCK, 1998), 62.

\title{
Christianity with an Asian Face: Asian American Theology in the Making. Peter C. Phan. Maryknoll: Orbis Press, 2003, xvi + $253 \mathrm{pp}$.
}

\author{
In Our Own Tongues: Perspectives from Asia on Mission and \\ Inculturation. Peter C. Phan. Maryknoll: Orbis Press, 2003, xiii + \\ $220 \mathrm{pp}$.
}




\section{Being Religious Interreligiously: Asian Perspectives on Interfaith Dialogue. Peter C. Phan. Maryknoll: Orbis Press, 2004, xxvii +283 pp.}

Peter C. Phan, Ignacio Ellacuria Professor of Catholic Social Thought at Georgetown University, describes this three volume set as a "trilogy" modeled on the "triple dialogue" with Asian poverty, cultures and religions promoted by the Federation of Asian Bishops' Conferences since 1970 (IOOT, xi). "Trinity" might be a better descriptor, since each collection of essays focuses on its major theme in explicit relation to the other two: picking up any one volume offers an apt introduction to the whole. Christianity with an Asian Face and In Our Own Tongues focuses on liberation theology and inculturation, respectively. Yet Phan argues that such inculturation cannot hope to make progress without vital engagement with the texts, traditions and popular piety of Asian religions, as well as illustrating the fruitful ways in which "the very nature" of interreligious dialogue finds itself transformed by liberative praxis (CAF, 32-33). Similarly, although the central section of Being Religious Interreligiously (chs. 5-12) treats a range of issues in interreligious dialogue, these chapters are framed by others that deal with theological education and liturgical inculturation. The overall effect of the three works is cumulative rather than linear; at the end of the odyssey, one is left with the ineluctable impression that -at least in the context of Asia and the Asian diasporas-these three activities are not so easily separated.

One great virtue of Phan's study also emerges, as often happens, as a kind of vice, especially from the point of view of comparative study: that is, Phan aims to speak about Christian theology and Asian identity in a comprehensive way. Such comprehensiveness is evident not only in the sheer volume of topics he treats-37 essays in all, each of which could have (and, in most cases, already have) stood alone. More importantly, it manifests in his willingness to generalize broadly about relations between Christianity and other religions. This is especially evident in Phan's various treatments of Hinduism. $\mathrm{He}$ is certainly familiar with Indian contextual Christian theologies, and he touches briefly on attempts to re-understand Trinity in such terms as the trimurti of Brahma, Vishnu and Shiva (IOOT, 183; BRI, 118-19). Elsewhere, he draws on Hinduism to illustrate general Asian religious trends against socio-political engagement or toward a vision of cosmic harmony (CAF, 92; IOOT, 143; BRI, 124-25). In a critique of Pope John Paul II's encyclical Fides et Ratio, moreover, he appeals to what he seems to regard as an intrinsically pluralistic orientation of "Asian philosophies" as such. To illustrate the point, he draws on the example of "Indian philosophies," which differentiate between "necessarily plural manifestations" and the "unity of all things in the universal self (Brahman, Atman)" (CAF, 63). Such generalizations overlook the genuine variety in Hindu traditions of devotion, activism and inquiry, of course, as well as blunting the often sharp rhetoric by which proponents negotiate their disagreements.

Nevertheless, Phan's comprehensive approach nicely contextualizes some aspects of Hindu-Christian study-at least, from the Christian side of the conversation. In an essay entitled "Multiple Religious Belonging" (BRI, ch. 4), for example, Phan places Henri Le Saux, Bede Grifffiths and Raimon Panikkar together with other "pioneers of multiple religious belonging" to establish a helpful "composite sketch" of the phenomenon (BRI, 70-71). In another, entitled "The Holocaust" (BRI, ch. 11), he first exposes the implicit anti-Judaism of selected liberation theologians in Asia and then attempts to bring them into constructive dialogue with Jewish Holocaust theology. 
Finally, he mines his own prior study of Alexandre de Rhodes' $17^{\text {th }}$ century mission in Vietnam to offer an appreciative critique of the comparative theological project of Francis X. Clooney (IOOT, ch. 9). In response to Clooney, Phan commends a comparative strategy that moves beyond texts to popular devotion: "it is important and necessary, as de Rhodes has shown, to go beyond texts to religions as actually lived at the popular level ..." (171). In each case, Phan attempts to draw those engaged in dialogue from the particular boundaries they occupy back into broader Catholic, Christian and extra-Christian discussions about mission and identity.

Though it takes up each aspect of the "triple dialogue" in turn, Phan's trilogy finds its true heart and center in one central task: discerning the features of a truly Asian Christianity (or even Christianities). Phan treats the topic from many angles; the "reception" of the Second Vatican Council and subsequent teachings of the Catholic Magisterium in Asia, the "new way of being church" promoted by the bishops of Asia through the vehicles of the FABC and the 1998 Asian Synod, the contribution from Asia to teaching and theologizing in the affluent West, and the perils and possibilities of a worship that is thoroughly Christian and thoroughly Asian at one and the same time. Along the way, he also offers some very good examples of theological reasoning across the bounds of culture and religion, especially in his native Vietnam. "Jesus as the Eldest Son and Ancestor" (CAF, ch. 6), "Mary in Vietnamese Piety and Theology (IOOT, ch. 6), and "How Much Uniformity Can We Stand? How Much Unity Do We Want?" (BRI, ch. 14) are particularly noteworthy in this regard.

I began this review by observing that "trinity" might describe these books better than "trilogy." In several places, Phan himself highlights the importance of the Trinity as the most fundamental Christian doctrine, in part because he finds in it an "inherent bias" toward "plurality and diversity" (BRI, xxxi-xxii). To read these volumes is indeed to enter into conversation with a genuine plurality of diverse positions, traditions and concerns. Despite its limitations, it is a highly impressive and worthwhile conversation to enter.

Reid B. Locklin

University of Toronto

\section{Gurus in America. Edited by Thomas A. Forsthoefel and Cynthia Ann Humes. Albany: State University of New York Press, 2005, $236 \mathrm{pp}$.}

THIS book provides perhaps the best available introduction to what the editors call the "second wave of gurus in America" (p.4), the first having begun with the arrival of Swami Vivekananda at the World Parliament of Religions in Chicago in 1893 followed by the emergence of Swami Paramananda, Paramahansa Yogananda, and Jiddu Krishnamurti. Despite the book's title the influence of the nine guru movements covered extends well beyond the U.S. to other nations and continents. Moreover, not all these spiritual teachers have themselves lived in the West; it is sufficient for their followers to have sunk roots in the West to merit inclusion in this study. In addition, Gurus in America does not claim to be exhaustive in its selection of Hindu spiritual guides living in the West - Swami Satchidananda and Swami Rama are notably absent - yet the nine men and women gurus selected represent well the wide range of Hindu teachings, practices, and models of authority one may encounter today in the quest for wholeness and spiritual growth. 